\title{
Arginase and pulmonary diseases
}

\author{
Harm Maarsingh • Tonio Pera $\cdot$ Herman Meurs
}

Received: 22 January 2008 / Accepted: 17 March 2008 / Published online: 24 April 2008

(C) The Author(s) 2008

\begin{abstract}
Recent studies have indicated that arginase, which converts L-arginine into L-ornithine and urea, may play an important role in the pathogenesis of various pulmonary disorders. In asthma, chronic obstructive pulmonary disease (COPD) and cystic fibrosis, increased arginase activity in the airways may contribute to obstruction and hyperresponsiveness of the airways by inducing a reduction in the production of bronchodilatory nitric oxide (NO) that results from its competition with constitutive (cNOS) and inducible (iNOS) NO synthases for their common substrate. In addition, reduced L-arginine availability to iNOS induced by arginase may result in the synthesis of both NO and the superoxide anion by this enzyme, thereby enhancing the production of peroxynitrite, which has procontractile and pro-inflammatory actions. Increased synthesis of L-ornithine by arginase may also contribute to airway remodelling in these diseases. LOrnithine is a precursor of polyamines and L-proline, and these metabolic products may promote cell proliferation and collagen production, respectively. Increased arginase activity may also be involved in other fibrotic disorders of the lung, including idiopathic pulmonary fibrosis. Finally, through its action of inducing reduced levels of vasodilating NO, increased arginase activity has been associated with primary and secondary forms of pulmonary hypertension. Drugs targeting the arginase pathway could have therapeutic potential in these diseases.
\end{abstract}

This review is dedicated to Professor Johan Zaagsma

H. Maarsingh $(\bowtie) \cdot$ T. Pera $\cdot$ H. Meurs

Department of Molecular Pharmacology,

University Centre for Pharmacy, University of Groningen,

Antonius Deusinglaan 1,

9713 AV Groningen, the Netherlands

e-mail: h.maarsingh@rug.nl
Keywords Arginase $\cdot$ Asthma Chronic obstructive pulmonary disease $\cdot$ Cystic fibrosis $\cdot$ Nitric oxide . Pulmonary hypertension

\section{Introduction}

Arginase, which converts L-arginine into L-ornithine and urea, is a key enzyme of the urea cycle in the liver, but it is also expressed in cells and tissues that lack a complete urea cycle, including the lung. Arginase exists as two distinct isoenzymes, arginase I and II, which are encoded by different genes. Arginase I is a cytosolic enzyme and is the predominant isoform in the liver, where it is highly expressed (Jenkinson et al. 1996; Wu and Morris 1998). Although low levels of arginase II have been detected in liver as well (Klasen et al. 2001), this mitochondrial enzyme is mainly expressed in extrahepatic tissue (Jenkinson et al. 1996; Wu and Morris 1998). In the airways, both arginase I and II are constitutively expressed in bronchial epithelial cells, endothelial cells, (myo)fibroblasts and alveolar macrophages (Klasen et al. 2001; Lindemann and Racke 2003; Que et al. 1998), while arginase II is also expressed in parenchymal epithelial cells (Que et al. 1998). A number of studies have reported that arginase expression in airway smooth muscle was below detection limit (e.g. Que et al. 1998), while other studies have indicated that either isoform may be (conditionally) expressed in these cells (Bergeron et al. 2007; Zuyderduyn et al. 2006).

One of the biological functions of extrahepatic arginase may be regulation of the synthesis of nitric oxide (NO) by means of competition with NO synthase (NOS) for the common substrate, L-arginine (Fig. 1). In activated macrophages, for example, arginase activity limits the utilization of L-arginine by inducible NOS (iNOS) and suppresses the 


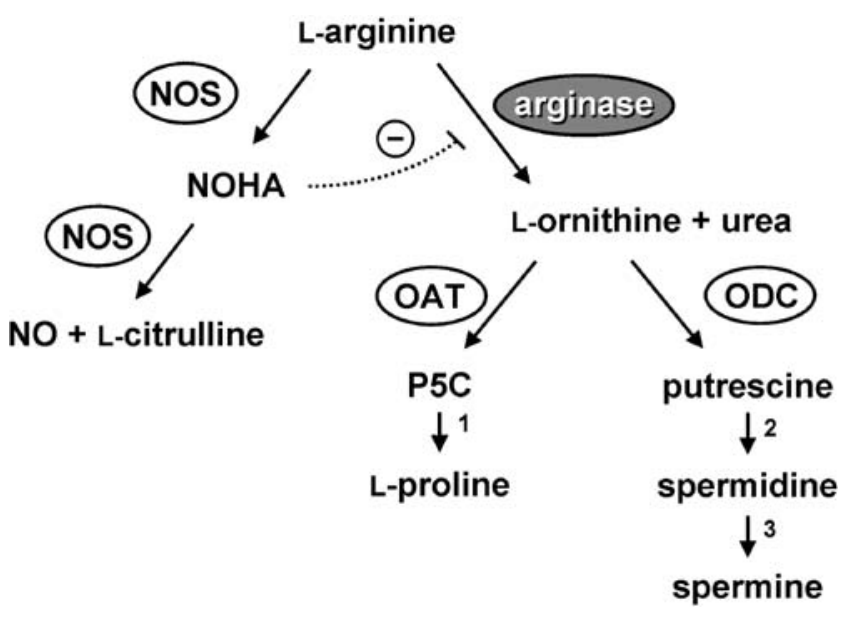

Fig. 1 L-Arginine metabolism catalysed by arginase and nitric oxide synthase $(N O S)$. L-Arginine is a substrate of both NOS, yielding nitric oxide $(N O)$ and L-citrulline, and arginase, which in turn produces Lornithine and urea. Arginase regulates the production of $\mathrm{NO}$ by competing with NOS for their common substrate. On the other hand, $\mathrm{N}^{\omega}$-hydroxy-L-arginine (NOHA), an intermediate in the NO synthesis catalysed by NOS, inhibits arginase activity. In addition, the arginase product L-ornithine is the precursor of the polyamines putrescine, spermidine and spermine and of L-proline. OAT Ornithine aminotransferase, $O D C$ ornithine decarboxylase, P5C L-pyrroline-5-carboxylate, 1 pyrroline-5-carboxylate reductase, 2 spermidine synthase, 3 spermine synthase

cytotoxic response by these cells (Hey et al. 1997; Modolell et al. 1995; Wang et al. 1995). The activity of arginase, however, is inhibited by $\mathrm{N}^{\omega}$-hydroxy-L-arginine (NOHA), an intermediate in the NO synthesis. This interaction demonstrates the delicate balance between NOS and arginase activity in the control of NO production (Boucher et al. 1994; Daghigh et al. 1994). In addition, extrahepatic arginase may be involved in tissue repair processes through the synthesis of L-ornithine. Thus, L-ornithine is a precursor of polyamines and L-proline, which are involved in cell proliferation and collagen synthesis, respectively (Satriano 2004; Shearer et al. 1997; Wu and Morris 1998).

A functional role for constitutively expressed arginase in the airways has been established in guinea pig tracheal preparations using the specific arginase inhibitor $\mathrm{N}^{\omega}$ hydroxy-nor-L-arginine (nor-NOHA). Thus, nor-NOHA decreased methacholine-induced airway constriction by increasing the production of non-neural, presumably epithelium-derived, bronchodilating NO (Meurs et al. 2000). Moreover, the arginase inhibitor increased NOmediated airway smooth muscle relaxation induced by inhibitory nonadrenergic noncholinergic (iNANC) nerve stimulation (Maarsingh et al. 2005). In both studies, the effects of nor-NOHA were quantitatively similar to the effects of exogenously applied L-arginine, thereby providing experimental evidence that arginase is involved in the control of airway responsiveness through attenuation of substrate availability to NOS (De Boer et al. 1999; Maarsingh et al. 2005; Meurs et al. 2000).

Aberrant NO homeostasis as well as exaggerated tissue repair are involved in various inflammatory airway diseases associated with reduced lung function, airway hyperresponsiveness (AHR) and/or airway remodelling, such as allergic asthma (Meurs et al. 2003; Ricciardolo et al. 2004), chronic obstructive pulmonary disease (COPD; Barnes et al. 2003; Hogg 2004; Postma and Kerstjens 1998) and cystic fibrosis (Hays et al. 2005; Hilliard et al. 2007; Tiddens and De Jong 2007). In addition, reduced levels of NO have also been observed in lungs of patients with pulmonary arterial hypertension (PAH; Kaneko et al. 1998), while dysregulated tissue repair and excessive fibrosis in the lung interstitium are observed in patients with idiopathic pulmonary fibrosis (Gross and Hunninghake 2001). This review will address the potential role of arginase in the pathophysiology of these diseases.

\section{Allergic asthma}

Role of NO in allergic asthma

Allergic asthma is a chronic inflammatory airways disease, characterized by allergen-induced early and late bronchial obstructive reactions and AHR to a variety of stimuli, including allergens, chemical irritants, cold air and pharmacological agents, such as histamine and methacholine (Bousquet et al. 2000). The development of bronchial obstructive reactions as well as of AHR is associated with an infiltration and activation of inflammatory cells, particularly Th2 lymphocytes and eosinophils, in the airways (Bousquet et al. 2000). The cause of AHR may be multifactorial, involving changes in both the neurogenic and non-neurogenic control of airway smooth muscle function as well as structural changes in the airways, such as epithelial damage, mucosal swelling and airway remodelling that is characterized by increased airway smooth muscle mass, subepithelial fibrosis, hyperplasia of mucous cells and angiogenesis (Bousquet et al. 2000). All of these changes can be induced by a cascade of inflammatory reactions involving various mediators, including NO (Bousquet et al. 2000; Ricciardolo et al. 2004; Ricciardolo 2003).

Nitric oxide is produced by a family of NOS isoforms that convert L-arginine into $\mathrm{NO}$ and L-citrulline using oxygen and NADPH as cosubstrates (Moncada et al. 1989). Three NOS isozymes have been identified to date: neuronal NOS (nNOS or NOS I), inducible NOS (iNOS or NOS II) and endothelial NOS (eNOS or NOS III). In the respiratory tract, nNOS and/or eNOS are constitutively expressed in iNANC neurons (nNOS) and in epithelial 
(nNOS and eNOS) and endothelial (eNOS) cells. These constitutive NOS (cNOS) isoenzymes are primarily involved in the neural and non-neural regulation of airway and vascular smooth muscle tone via both cGMPdependent and-independent mechanisms (Ricciardolo et al. 2004). In addition, eNOS-derived NO has been shown to inhibit airway inflammation by suppressing the activation of NF-kB, thereby inhibiting both the expression of iNOS and the production of inflammatory cytokines (Cirino et al. 2003; Cook et al. 2003; Marshall and Stamler 2001; Ten Broeke et al. 2006; Thomassen et al. 1997). A number of studies have demonstrated that an impaired production of cNOS-derived bronchodilating NO contributes to the development of AHR in allergic asthma, both in animal models and in human asthma (De Boer et al. 1996; Maarsingh et al. 2006; Mehta et al. 1997; Ricciardolo et al. 1997, 2001; Samb et al. 2001; Schuiling et al. 1998b).

Inducible NOS is induced in the airways through the action of pro-inflammatory cytokines, particularly those found in inflammatory and epithelial cells (Asano et al. 1994; Barnes 1998; Hamid et al. 1993). Inducible NOSderived NO may be involved in the infiltration of inflammatory cells (Schuiling et al. 1998a), mucosal swelling (Kuo et al. 1992) and epithelial damage (Flak and Goldman 1996; Schuiling et al. 1998a), but it may also have a beneficial bronchodilating action (De Gouw et al. 1998; Schuiling et al. 1998a), indicating a dualistic role in the airways. In contrast to cNOS, iNOS produces large amounts of NO, which causes increased concentrations of NO in the exhaled air of asthmatics (Kharitonov et al. 1994). In experimentally induced asthma, iNOS is induced in the airways during the allergen-induced late asthmatic reaction, similarly leading to increased levels of NO in the exhaled air (Kharitonov et al. 1995a; Yan et al. 1995). In asthmatics, increased nitrotyrosine staining in the airways correlates well with iNOS expression, AHR and airway inflammation, suggesting that not iNOS-derived NO itself but, rather, its reaction with superoxide to the highly reactive oxidant peroxynitrite may be an important factor accounting for the detrimental effects of iNOS in the airways (Saleh et al. 1998). Indeed, peroxynitrite has procontractile and proinflammatory actions and is involved in the development of AHR after the late asthmatic reaction or after repeated allergen challenge (De Boer et al. 2001; Muijsers et al. 2001; Sadeghi-Hashjin et al. 1996, 1998).

Arginase in animal models of allergic asthma

A study using a guinea pig model of allergic asthma and ovalbumin-sensitized animals demonstrated that a deficiency of NO underlies the development of AHR following the allergen-induced early asthmatic reaction (De Boer et al.
1996; Schuiling et al. 1998b) and that this NO deficiency is caused by a decreased availability of L-arginine to cNOS (De Boer et al. 1999; Maarsingh et al. 2006; Meurs et al. 2002). Using airway preparations from the same animal model, it was demonstrated that increased arginase activity may be involved in the reduced L-arginine bioavailability and AHR. Thus, arginase activity in the airways of allergen-challenged guinea pigs was 3.5-fold increased after the early asthmatic reaction as compared to unchallenged animals, while incubation with the arginase inhibitor nor-NOHA completely reversed the allergen-induced AHR of perfused tracheal preparations from these animals by restoring NO production (Meurs et al. 2002). L-Arginine limitation induced by increased arginase activity also appeared to underlie an impaired iNANC nerve-mediated airway smooth muscle relaxation after the early asthmatic reaction by inducing a deficiency of nNOS-derived NO (Maarsingh et al. 2006). Collectively, these findings indicate a key role for arginase in the development AHR following the allergen-induced early asthmatic reaction by inducing a deficiency of both neuronal and non-neuronal NO (Fig. 2).

A second mechanism by which increased arginase activity may contribute to AHR in allergic asthma is through the stimulation of peroxynitrite formation. Studies in macrophages have indicated that under conditions of low L-arginine availability iNOS not only produces NO by its oxygenase moiety, but also synthesizes superoxide anions by its reductase moiety, leading to an efficient formation of peroxynitrite (Xia et al. 1998). Increasing the L-arginine concentration in these cells stimulates NO production, while the formation of superoxide - and hence peroxynitrite - is reduced (Xia and Zweier 1997). In perfused guinea pig tracheal preparations obtained after the allergen-induced late asthmatic reaction, the AHR to methacholine was reduced by both the NOS inhibitor L-NAME and the superoxide anion scavenger superoxide dismutase (SOD), indicating the involvement of peroxynitrite in this process (De Boer et al. 2001). Remarkably, the AHR was similarly diminished by the arginase inhibitor nor-NOHA and by exogenous L-arginine, which is highly suggestive of the reduced L-arginine availability caused by increased arginase activity being involved in the iNOS-induced production of peroxynitrite and AHR (Maarsingh et al. 2004). This mechanism was underscored by the observation that the effect of nor-NOHA was fully reversed by L-NAME, indicating that arginase inhibition restores the production of bronchodilating NO. Moreover, the arginase activity in the tracheal tissue and bronchoalveolar lavage cells of the challenged animals was increased after the late asthmatic reaction (Maarsingh et al. 2004).

The importance of increased arginase activity in the pathophysiology of asthma has been confirmed in various 


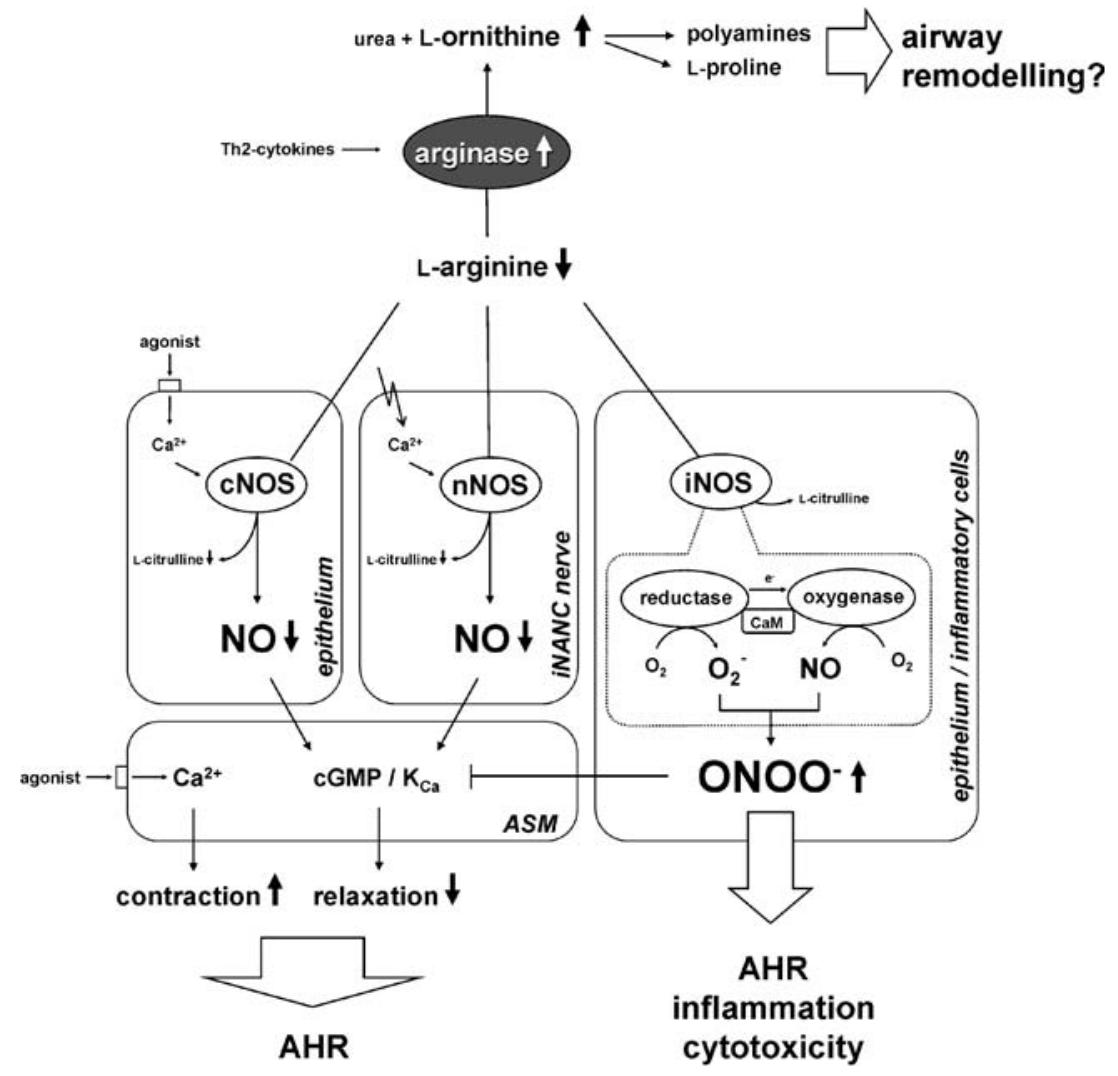

Fig. 2 Role of increased arginase activity in the pathophysiology of allergic asthma. In allergic asthma, both arginase expression and activity are increased by $\mathrm{Th} 2$-cytokines. Increased arginase activity limits the bioavailability of L-arginine to constitutive nitric oxide synthase $(c N O S)$, leading to a reduced production of agonist-induced nitric oxide $(N O)$ by the airway epithelium and neuronal NO by inhibitory nonadrenergic noncholinergic $(i N A N C)$ nerves. Under basal conditions, NO induces airway smooth muscle relaxation by increasing the production of cyclic $3^{\prime}, 5^{\prime}$ guanosine monophosphate (cGMP) and/or by opening of calcium-activated potassium channels, thereby attenuating the responsiveness of the airways to contractile stimuli. As a result, arginase-induced deficiency of cNOS-derived NO in allergic asthma contributes to airway hyperresponsiveness $(A H R)$ in this

animal models of allergic asthma and using different antigens. Increased arginase activity in the lung was measured after allergen challenge in $\mathrm{BALB} / \mathrm{c}$ mice sensitized to ovalbumin and to Aspergillus fumigatus (Zimmermann et al. 2003). Notably, microarray analysis of gene expression revealed that among the 291 common genes that are induced by these allergens, enzymes involved in L-arginine metabolism, particularly arginase I and II, belong to the most predominantly overexpressed genes. Northern blot analysis confirmed the increase in arginase I and II gene expression; however, in contrast to arginase I, arginase II was constitutively present, but induced to a much lesser extent. In situ hybridization and immunohistochemistry of ovalbumin-challenged animals demonstrated the presence of high levels of arginase I in the perivascular and peribronchial pockets of inflammation disease. Increased arginase activity also attenuates the availability of L-arginine to inducible nitric oxide synthase (iNOS), which is induced during the late asthmatic reaction or in chronic asthma. The reduced Larginine availability to iNOS results in the simultaneous production of $\mathrm{NO}$ and the $\mathrm{O}_{2}{ }^{-}$superoxide anion by the oxygenase and reductase moieties of the enzyme, respectively, This leads to the rapid formation of the highly reactive nitrogen species peroxynitrite $\left(\mathrm{ONOO}^{-}\right)$, which has procontractile, proinflammatory and cytotoxic actions in the airways. In addition, increased production of polyamines and Lproline downstream of L-ornithine may contribute to the process of airway remodelling. ASM Airway smooth muscle, $\mathrm{CaM}$ calmodulin; $e^{-}$electron, $K_{C a}$ calcium-activated potassium channel, $n N O S$ neuronal nitric oxide synthase

in the asthmatic lung (Zimmermann et al. 2003). In line with the results of the microarray study mentioned above, proteomics of lung tissue from repeatedly ovalbuminchallenged C57BL/6 mice showed a considerable upregulation of arginase I (Fajardo et al. 2004).

Based on results from earlier studies in mouse macrophages (Corraliza et al. 1995; Modolell et al. 1995), lung arginase activity and mRNA expression of both arginase I and arginase II are strongly induced by the Th2 cytokines interleukin (IL)-4 and IL-13, which are abundant in allergic airway inflammation (Zimmermann et al. 2003). More recently, IL-25, a novel member of the IL-17 family which induces Th2-like airway inflammation and AHR, has also been shown to increase arginase I mRNA expression in mouse lung (Sharkhuu et al. 2006). Increased arginase I gene expression was also observed in Th2-polarized-but 
not in Th1 polarized - mice sensitized to and challenged with Schistosoma mansoni eggs (Sandler et al. 2003), supporting the importance of Th2 cytokines in inducing arginase in asthma. Although IL-4 alone did not induce arginase activity in human alveolar macrophages, it greatly enhanced the response to cAMP-elevating agents (Erdely et al. 2006). Zuyderduyn et al. (2006) recently demonstrated that isolated human airway smooth muscle cells have a particularly low expression of arginase II; remarkably, the expression of arginase II, but not of arginase I, increased after stimulation with IL-4 (Zuyderduyn et al. 2006). Of note, in rat vascular smooth muscle cells, the expression of arginase I was induced by IL-4 as well as by IL-13, while arginase II was not induced by these cytokines (Wei et al. 2000).

Several studies have indicated that the transcription factors STAT6 (Gray et al. 2005; Rutschman et al. 2001; Wei et al. 2000; Yang et al. 2006; Zimmermann et al. 2003) and CCAAT-enhancer binding protein (Gray et al. 2005) are key factors regulating the control of cytokineinduced expression of arginase I. However, IL-4-induced arginase II expression in the lung was hardly affected in $\mathrm{STAT}^{-/-}$mice, indicating that the induction of arginase II is largely STAT6-independent (Zimmermann et al. 2003).

Lung arginase activity and arginase I mRNA expression were also increased in BALB/c mice challenged with trimellitic anhydride, although the induction was lower than in animals challenged with ovalbumin (Greene et al. 2005). In addition, lung arginase activity as well as mRNA and protein expression of both arginase I and II have been shown to be increased in NC/Nga mice challenged with Dermatophagoides farinae (Takemoto et al. 2007). While arginase I was not detected in the lung of control animals, increased arginase I expression was observed in alveolar macrophages and the infiltrating cells around the bronchioles in challenged mice (Takemoto et al. 2007). In different mouse models of Th2 cytokine-mediated inflammation in which ovalbumin (BALB/c and C57BL/6 mice), the parasite Nippostrongylus brasiliensis $(\mathrm{BALB} / \mathrm{c})$ or the fungus Aspergillus fumigatus (C57BL/6) was used as well as in IL-13 overexpressing mice, gene expression in the lung was studied to identify the genes that are commonly expressed in lung inflammation. Among the 26 characteristic transcripts of these five different models, arginase I was strongly increased in all (Lewis et al. 2007). In another study in mice, instillation of IL-13 in the airways increased arginase activity and the expression of arginase I, but not of arginase II, while NO synthesis was decreased (Yang et al. 2006). Interleukin-13-induced arginase expression was also temporally correlated with the development, persistence and resolution of IL-13-induced AHR to methacholine. In vivo treatment with RNA interference against arginase I abrogated the development of IL-13-induced AHR, sup- porting the importance of increased arginase activity for AHR in asthma (Yang et al. 2006). Further studies demonstrating the effects of specific arginase inhibitors and/or RNA interference against arginase I and II on allergen-induced AHR are clearly indicated.

In addition to guinea pig and mice models of asthma, increased arginase activity has also been observed in a rat model of allergic asthma. Thus, arginase activity was observed to increase in lung homogenates of rats challenged with ovalbumin for 3 consecutive days (Abe et al. 2006).

Taken together, increased arginase induction has been observed in a wide variety of animal models of asthma, using different species and allergens (Table 1). The increased arginase activity may contribute to AHR by reducing the production of bronchodilating $\mathrm{NO}$ as well as by stimulating the formation of procontractile and proinflammatory peroxynitrite (Fig. 2). Interestingly, it was recently demonstrated in lung epithelial cells that overexpression of arginase may increase NF- $\mathrm{KB}$ activation through a decreased production of $\mathrm{NO}$, suggesting that increased arginase activity in allergic asthma could also promote airway inflammation and AHR by increasing the production of inflammatory cytokines (Ckless et al. 2007).

Arginase in human asthma

The significance of increased arginase expression and activity on the pathophysiology of human asthma was first reported by Zimmermann et al. (2003), who demonstrated that arginase I protein expression increases in bronchoalveolar lavage (BAL) cells of asthmatic patients. Moreover, bronchial biopsies of these patients revealed enhanced mRNA expression of arginase I in both the inflammatory cells and in the airway epithelium. Surprisingly, elevated levels of arginase activity were found in the serum of asthmatic patients experiencing an exacerbation, which was associated with reduced plasma L-arginine levels, indicating that changes in arginase expression in asthma are not confined to the airways and that reduced levels of circulating L-arginine could contribute to NO deficiency and hyperresponsiveness of the airways (Morris et al. 2004). These researchers also observed that arginase activity declined and L-arginine concentrations increased in some of these patients following an improvement of symptoms (Morris et al. 2004). It is worth noting that enhanced arginase activity in expectorated sputum of asthmatic patients had been reported over two decades ago (Kochanski et al. 1980).

Bergeron et al. (2007) recently published their findings on the effect of smoking on arginase expression in human airways. Endobronchial biopsy specimens from steroidnaïve mild asthmatics were investigated for changes in 
Table 1 Changes in arginase activity and the expression of arginase I and II in animal models and human pathology of pulmonary diseases

\begin{tabular}{|c|c|c|c|c|c|c|c|}
\hline Clinical condition & Species & $\begin{array}{l}\text { Condition/ } \\
\text { stimulus }^{\mathrm{a}}\end{array}$ & Localization $^{\mathrm{b}}$ & $\begin{array}{l}\text { Arginase } \\
\text { I }\end{array}$ & $\begin{array}{l}\text { Arginase } \\
\text { II }\end{array}$ & Activity & References \\
\hline \multirow[t]{14}{*}{ Asthma } & \multirow[t]{4}{*}{ Human } & & Sputum & n.d. & n.d. & + & Kochanski et al. 1980 \\
\hline & & & Serum & n.d. & n.d. & + & Morris et al. 2004 \\
\hline & & & $\begin{array}{l}\text { BAL cells, } \\
\text { epithelium, } \\
\text { lung, } \mathrm{M} \Phi\end{array}$ & + & n.d. & n.d. & Zimmermann et al. 2003 \\
\hline & & Cigarette smoke & $\begin{array}{l}\text { Smooth } \\
\text { muscle, } \\
\text { epithelium }\end{array}$ & + & n.d. & n.d. & Bergeron et al. 2007 \\
\hline & $\begin{array}{l}\text { Guinea } \\
\text { pig }\end{array}$ & Ovalbumin & $\begin{array}{l}\text { BAL cells, } \\
\text { trachea }\end{array}$ & n.d & n.d. & + & $\begin{array}{l}\text { Maarsingh et al. 2004; Meurs } \\
\text { et al. } 2002\end{array}$ \\
\hline & \multirow[t]{8}{*}{ Mouse } & $\begin{array}{l}\text { Aspergillus } \\
\text { fumigatus }\end{array}$ & Lung & + & + & + & $\begin{array}{l}\text { Lewis et al. 2007; Zimmermann } \\
\text { et al. } 2003\end{array}$ \\
\hline & & $\begin{array}{l}\text { Dermatophagoides } \\
\text { farinae }\end{array}$ & $\begin{array}{l}\text { Lung, serum, } \\
\mathrm{M} \Phi\end{array}$ & + & + & + & Takemoto et al. 2007 \\
\hline & & IL-4 & Lung & + & + & n.d. & Zimmermann et al. 2003 \\
\hline & & IL-13 & Lung & + & $+/=$ & + & $\begin{array}{l}\text { Lewis et al. 2007; Yang et al. } \\
\text { 2006; Zimmermann et al. } 2003\end{array}$ \\
\hline & & $\begin{array}{l}\text { Nippostrongylus } \\
\text { brasiliensis }\end{array}$ & Lung & + & $=$ & n.d. & Lewis et al. 2007 \\
\hline & & Ovalbumin & Lung, $\mathrm{M} \Phi$ & + & + & + & $\begin{array}{l}\text { Fajardo et al. 2004; Greene et al. } \\
\text { 2005; Lewis et al. 2007; } \\
\text { Zimmermann et al. } 2003\end{array}$ \\
\hline & & $\begin{array}{l}\text { Schistosoma } \\
\text { mansoni eggs }\end{array}$ & Lung & + & n.d. & n.d. & Sandler et al. 2003 \\
\hline & & TMA & Lung & + & + & + & Greene et al. 2005 \\
\hline & Rat & Ovalbumin & Lung & n.d. & n.d. & + & Abe et al. 2006 \\
\hline \multirow{3}{*}{$\begin{array}{l}\text { Chronic obstructive } \\
\text { pulmonary disease } \\
\text { (COPD) }\end{array}$} & \multirow[t]{2}{*}{ Human } & & Sputum & n.d. & n.d. & + & $\begin{array}{l}\text { Chachaj et al. 1978; Kochanski } \\
\text { et al. } 1980\end{array}$ \\
\hline & & GOLD 0, I, II-A & Lung & $=$ & $=$ & n.d. ${ }^{\mathrm{c}}$ & Tadie et al. 2008 \\
\hline & Rat & Cigarette smoke & Lung & + & n.d. & n.d. & Gebel et al. 2006 \\
\hline Cystic fibrosis (CF) & Human & & $\begin{array}{l}\text { Plasma, } \\
\text { sputum, }\end{array}$ & n.d. & n.d. & + & Grasemann et al. $2005 b ; 2006 b$ \\
\hline \multirow[t]{6}{*}{ Fibrosis } & \multirow[t]{2}{*}{ Human } & IPF & Lung & - & $=$ & $=$ & Kitowska et al. 2008 \\
\hline & & IPF & $\begin{array}{l}\text { Epithelium, } \\
\text { fibroblasts, } \\
\text { lung, M } \Phi\end{array}$ & + & n.d. & n.d. & Mora et al. 2006 \\
\hline & \multirow[t]{3}{*}{ Mouse } & Bleomycin & $\begin{array}{l}\text { Epithelium, } \\
\text { fibroblasts, } \\
\text { lung, M } \Phi\end{array}$ & + & + & n.d. & $\begin{array}{l}\text { Endo et al. 2003; Kitowska et } \\
\text { al. } 2008\end{array}$ \\
\hline & & Herpes virus & Lung, $\mathrm{M} \Phi$ & + & n.d. & + & Mora et al. 2006 \\
\hline & & Silica & $\begin{array}{l}\text { BAL cells, } \\
\text { lung, } \mathrm{M} \Phi\end{array}$ & + & n.d. & + & Misson et al. 2004 \\
\hline & Rat & Silica & $\begin{array}{l}\text { BAL cells, } \\
\text { lung }\end{array}$ & + & $=$ & + & $\begin{array}{l}\text { Nelin et al. 2002; Poljakovic et } \\
\text { al. 2007; Schapira et al. } 1998\end{array}$ \\
\hline \multirow{4}{*}{$\begin{array}{l}\text { Pulmonary } \\
\text { hypertension }(\mathrm{PH})\end{array}$} & \multirow[t]{2}{*}{ Human } & Primary $\mathrm{PH}$ & PAEC, serum & $=$ & + & + & $\mathrm{Xu}$ et al. 2004 \\
\hline & & $\begin{array}{l}\text { Secondary } \mathrm{PH} \text { in } \\
\text { sickle cell disease }\end{array}$ & $\begin{array}{l}\text { Erythrocytes, } \\
\text { plasma, } \\
\text { serum }\end{array}$ & n.d. & n.d. & + & Morris et al. 2003; 2005 \\
\hline & Mouse & Haemoglobin $^{-/-}$ & Lung & n.d. & n.d. & + & Hsu et al. 2007 \\
\hline & Rat & Monocrotaline & PAEC & n.d. & n.d. & + & Sasaki et al. 2007 \\
\hline
\end{tabular}

-, Decreased; +, increased; =, unchanged, n.d., not determined

${ }^{a}$ IPF, Idiopathic pulmonary fibrosis; TMA, trimilletic anhydride; IL, interleukin

${ }^{\mathrm{b}} \mathrm{M} \Phi$, Macrophages; PAEC, pulmonary arterial endothelial cells; BAL cells, bronchoalveolar lavage cells

${ }^{\mathrm{c}}$ Arginase inhibition decreases the sensitivity to acetylcholine in COPD patients compared to control subjects 
immunoreactivity for arginase I, ornithine decarboxylase (ODC, the rate limiting enzyme in polyamine synthesis; Fig. 1) and iNOS in smoking versus non-smoking patients. Interestingly, increased immunoreactivity for arginase I and ODC was observed in both the epithelium and smooth muscle layers of the smokers, while iNOS-immunoreactivity was similar in both groups. In addition, arginase I mRNA expression was increased in the epithelium and smooth muscle bundles of smoking asthmatics as compared to the non-smoking patients. To investigate which component of cigarette smoke may attribute for the increase in arginase expression, these researchers studied the effect of nicotine on arginase and ODC expression in cultured airway epithelial and smooth muscle cells and fibroblasts. Nicotine significantly increased arginase I mRNA in the epithelial cells, while a trend towards increased arginase I mRNA expression was observed in airway smooth muscle cells and fibroblasts after nicotine treatment. In addition, nicotine significantly increased ODC mRNA expression in the fibroblasts and epithelial cells, but not in the airway smooth muscle cells (Bergeron et al. 2007). These observations may also be of relevance for the pathogenesis of COPD (see below).

Interestingly, single nucleotide polymorphisms (SNPs) in arginase I and arginase II have recently been found to be associated with atopy and the risk of childhood asthma, respectively ( $\mathrm{Li}$ et al. 2006).

\section{Chronic obstructive pulmonary disease}

Chronic obstructive pulmonary disease is an inflammatory disease characterized by a progressive, irreversible decline in lung function. The leading cause of COPD is cigarette smoke (Pauwels et al. 2001). Smoking initiates pulmonary inflammation characterized by the prominent infiltration of neutrophils, macrophages and T-lymphocytes, particularly those of the CD8 ${ }^{+}$subset (Jeffery 2000; Sutherland and Martin 2003). The main features of COPD are airway hyperresponsiveness and progressive decline in lung function associated with structural changes in the peripheral lung, including small airway remodelling that is characterized by mucus cell hyperplasia, airway fibrosis and increased airway smooth muscle mass- and alveolar wall destruction (Barnes et al. 2003; Hogg 2004; Jeffery 2000; Postma and Kerstjens 1998; Sutherland and Martin 2003).

Based on results obtained using the single expiratory flow technique to measure NO derived from the (predominantly larger) airways, COPD has been associated with increased levels of exhaled NO (eNO) in patients with severe stage disease and during exacerbations (Agusti et al. 1999; Bhowmik et al. 2005; Maziak et al. 1998). However, this method has also shown that eNO is often low or in the normal range in patients with stable COPD (Kharitonov and Barnes 2001), a state that has been attributed to the effect of tobacco smoking, which downregulates eNOS (Hutchison et al. 2001) and iNOS (Hoyt et al. 2003). Indeed, smokers exhale lower amounts of NO than nonsmokers (Kharitonov et al. 1995b). Reduced levels of NO may also result from smoking-induced increased oxidative stress through the formation of peroxynitrite from $\mathrm{NO}$ and superoxide anions. In support of this hypothesis, peroxynitrite generation has been found to be considerably increased in sputum macrophages of COPD patients, which is negatively correlated with forced expiratory volume in the first second $\left(\mathrm{FEV}_{1}\right)$ in these patients (Achenes et al. 2000). Measurements of eNO taken at multiple respiratory flows have indicated that, while airway NO is relatively low in COPD, there is an increase in alveolar NO that is related to disease severity and not affected by smoking (Brindicci et al. 2005).

Quite interestingly, microarray analysis of gene expression followed by reverse transcription real-time quantitative PCR in lungs from smoking rats revealed a marked timeand dose-dependent upregulation of arginase I expression during 2-13 weeks of smoke exposure $(2 \times 1 \mathrm{~h} /$ day, 5 days/ week; Gebel et al. 2006). Smoke-induced expression of arginase I may be involved in the relatively low NO production in the airways of COPD patients as well as in the peroxynitrite production and AHR found in these patients. The latter development is supported by the recent observation that increased arginase activity may be involved in the enhanced sensitivity to methacholine shown by bronchial preparations from patients with mild COPD (Tadie et al. 2008). Interestingly, subcutaneous injection ( 5 weeks, once daily) of cigarette smoke extract in rabbits increased the expression of arginase $\mathrm{I}$ and increased arginase activity in cavernous tissue, while NOS activity and nNOS expression were significantly decreased (Imamura et al. 2007). Moreover, electric field stimulationinduced neurogenic and NO-mediated cavernous smooth muscle relaxation was attenuated by cigarette smoke extract administration (Imamura et al. 2007). Whether cigarette smoke-induced increase in arginase activity in the airways also leads to reduced iNANC-mediated NO production and airway smooth muscle relaxation has yet to be studied.

As already mentioned, nicotine, a major constituent of tobacco smoke, may upregulate arginase I in airway structural cells (Bergeron et al. 2007). Interestingly, recent evidence suggests that human neutrophils constitutively express high levels of arginase I in azurophilic granules (Munder et al. 2005) which, like other constituents of these granules, including neutrophil elastase, may be liberated in patients with COPD (Renkema et al. 1991). Since neutrophil abundance is also demonstrated in patients with severe asthma as well as in those with cystic fibrosis, neutrophil arginase could also be involved in the pathogenesis of these 
diseases; however, the role of neutrophil arginase in airway diseases remains to be established. Remarkably, as with asthma, increased arginase activity in the sputum of COPD patients had already been found as early as the late 1970s (Chachaj et al. 1978; Kochanski et al. 1980).

\section{Cystic fibrosis}

Cystic fibrosis is a progressive disease, characterized by pulmonary inflammation and bacterial infection, chronic airway obstruction, airway remodelling and AHR (Hays et al. 2005; Hilliard et al. 2007; Tiddens and De Jong 2007). Despite the inflammatory nature of $\mathrm{CF}$, this disease is characterized by decreased levels of eNO (Elphick et al. 2001; Grasemann et al. 1997), and reduced NO levels in the airways of $\mathrm{CF}$ patients may contribute to microbial infection and colonization as well as to functional changes of the airways. Several mechanisms may contribute to the low pulmonary levels of $\mathrm{NO}$ in $\mathrm{CF}$, including a reduced expression of iNOS (Downey and Elborn 2000), polymorphisms of nNOS (Grasemann et al. 2000, 2002) and eNOS (Grasemann et al. 2003), mechanical retention of NO in airway secretions (Grasemann et al. 1998), increased metabolism to peroxynitrite (Robbins et al. 2000), consumption of NO by denitrifying bacteria (Gaston et al. 2002) and increased arginase activity in the airways (Grasemann et al. 2005b, 2006b).

In a mouse model of $\mathrm{CF}$, an impaired electrical field stimulation-induced airway smooth muscle relaxation was found, which was reversed by L-arginine and NO (Mhanna et al. 2001). This result indicates that a deficiency of NO due to substrate limitation to nNOS compromises airway relaxation and contributes to airway obstruction. In support of this mechanism, a positive correlation has been found between pulmonary function and exhaled $\mathrm{NO}$ and $\mathrm{NO}$ metabolite concentrations in the sputum of CF patients (Grasemann et al. 1997, 1998). Moreover, inhalation of Larginine increased exhaled NO levels and improved lung function in these patients (Grasemann et al. 2006a). However, oral L-arginine treatment increased L-arginine levels in sputum and plasma as well as levels of exhaled NO, but failed to improve pulmonary function (Grasemann et al. 2005a). Increased consumption by arginase may account for the L-arginine limitation in $\mathrm{CF}$, since sputum arginase activity in CF is markedly increased in comparison to controls and is even further increased during pulmonary exacerbation (Grasemann et al. 2005b). Interestingly, increased arginase activity was found to be negatively correlated with lung function $\left(\mathrm{FEW}_{1}\right)$, while increased eNO and improved lung function due to antibiotic treatment were associated with a decrease in arginase activity
(Grasemann et al. 2005b). At least some portion of the increased arginase activity in the above-mentioned study could have been derived from microorganisms in the sputum. However, increased arginase activity was also observed in plasma of $\mathrm{CF}$ patients during pulmonary exacerbation, while plasma L-arginine levels were decreased (Grasemann et al. 2006b). Treatment with antibiotics decreased the arginase activity and restored the L-arginine levels in these patients, thereby confirming the close relationship between increased arginase activity and decreased levels of L-arginine (Grasemann et al. 2006b). Taken together, these findings indicate that increased arginase activity in $\mathrm{CF}$ contributes to the NO deficiency and pulmonary obstruction in CF by limiting the availability of L-arginine to NOS.

\section{Arginase in airway remodelling and fibrotic pulmonary disorders}

Increased arginase activity in asthma, COPD and cystic fibrosis may also contribute to the airway remodelling observed in these diseases through the increased production of L-proline and the polyamines putrescine, spermidine and spermine from L-ornithine (Fig. 1, 2). L-Proline, the precursor of collagen, is synthesized from L-ornithine in a two-step reaction involving ornithine aminotransferase and pyrroline-5-carboxylate reductase, while ODC initiates the synthesis of polyamines that could be involved in the proliferation of structural cells in the airways (Hoet and Nemery 2000; Meurs et al. 2003; Ricciardolo et al. 2005; Wu and Morris 1998; Fig. 1). In support of this concept, transfection of rat vascular smooth muscle cells with arginase I induced increased polyamine levels and enhanced proliferation of these cells (Wei et al. 2001). The involvement of arginase in airway remodelling remains to be established, however. In support of a potential role of arginase in airway fibrosis in asthma, IL-4 and IL-13 increased arginase I and II expression and arginase activity in cultured rat fibroblasts (Lindemann and Racke 2003), and IL-4 induced increased arginase II expression in human airway smooth muscle cells (Zuyderduyn et al. 2006). In addition, increased levels of polyamines have been observed in the mouse lung after allergen challenge (Zimmermann et al. 2003) and in the serum of asthmatic patients (Kurosawa et al. 1992), respectively. Notably, growth factors, such as epidermal growth factor (EGF) and platelet-derived growth factor (PDGF), which are known to be enhanced in asthma, may be involved in the induction of arginase and of enzymes participating in the polyamine synthetic pathway (Nelin et al. 2005; Thyberg and Fredholm 1987a, b). Polyamines can stimulate the 
expression of genes implicated in cell proliferation by promoting histone acetyltransferase activity, resulting in chromatin hyperacetylation (Hobbs and Gilmour 2000). The activity of histone acetyltransferase was found to be increased in bronchial biopsies of asthmatic patients (Ito et al. 2002).

As mentioned above, exposure to cigarette smoke and/or nicotine may induce increased expression of arginase I and ODC in human airway structural cells (Bergeron et al. 2007). The results of a study showing that long-term exposure to mainstream smoke increased ODC activity in rat trachea and lung provides experimental support for this possibility (Olson 1985). That nicotine could account for the effect of cigarette smoke was shown by the observation that a single subcutaneous injection of nicotine also induced a transient increase in ODC activity in rat trachea (Olson and Crooks 1985). These findings suggest that smoking may contribute to airway remodelling in asthma as well as in COPD.

Expression of collagen I mRNA and arginase I and II mRNA and protein was increased in bleomycin-induced lung fibrosis in mice (Endo et al. 2003). Arginase II expression co-localized with the collagen-specific chaperone Hsp47, indicating a prominent role for arginase in collagen synthesis in lung fibrosis (Endo et al. 2003). In another study, Kitowska et al. (2008) observed a bleomycin-induced time-dependent increase in arginase I and II expression in mouse lung that was accompanied by decreased levels of L-arginine; arginase was localized to macrophages and epithelial cells as well as in interstitial fibroblasts, especially in fibrotic lesions. Increased arginase expression in fibrotic areas was also observed in herpes virus-induced lung fibrosis in mice (Mora et al. 2006). Interestingly, arginase I and II expression was induced by transforming growth factor (TGF)- $\beta$ in primary mouse fibroblasts, and treatment with the non-specific arginase inhibitor NOHA prevented the TGF- $\beta$-induced increase in collagen content in a posttranscriptional manner (Kitowska et al. 2008). In several animal models of silicosis, another inflammatory lung disease characterized by fibrosis, arginase activity and arginase I expression were also enhanced in lung and alveolar macrophages (Misson et al. 2004; Nelin et al. 2002; Poljakovic et al. 2007; Schapira et al. 1998). However, a direct relationship between increased arginase activity and expression and fibrosis has not always been found: Misson et al. (2004) reported that arginase I expression and activity in lung of silica-exposed mice were increased at 3 days, but not 30 or 60 days, following silica exposure, while levels of hydroxyproline - a marker of fibrosis - were increased at all three time points. A study involving treatment with an arginase inhibitor could clarify whether (increased) arginase activity is indeed involved in silica-induced fibrosis.
In line with the above findings in mouse models of lung fibrosis, arginase I expression was found to be increased in patients with idiopathic pulmonary fibrosis (IPF), especially in the alveolar macrophages, epithelial cells and areas with pleura thickening and interstitial fibrosis (Mora et al. 2006). However, in another study on IPF patients, lung arginase I expression was decreased, while no differences were observed in arginase II expression and arginase activity in the lung, nor in arginase I and II expression in cultured fibroblasts from these patients (Kitowska et al. 2008). Therefore, further investigation is needed to establish the role of arginase in human pulmonary fibrotic disease.

\section{Arginase and pulmonary hypertension}

Reduced levels of NO have been observed in lungs of patients with pulmonary hypertension ( $\mathrm{PH}$; Kaneko et al. 1998). These reduced NO levels may be caused by changes in L-arginine metabolism, since low levels of plasma Larginine have been found in patients with primary and secondary forms of hypertension (Morris et al. 2003, 2005; $\mathrm{Xu}$ et al. 2004). Inhalation of NO as well as L-arginine supplementation have shown to be of potential benefit in the treatment of PH (Atz and Wessel 1997; Morris et al. 2003, 2005). The decreased L-arginine levels may result from increased arginase activity, and increased arginase activity in serum has been detected in patients with primary $\mathrm{PH}(\mathrm{PPH})$, which was associated with reduced L-arginine to L-ornithine levels in these patients (Xu et al. 2004). Moreover, increased arginase II expression has been observed in PPH patients, especially in the endothelium of arteries and arterioles, as well as in cultured pulmonary arterial endothelial cells from these patients (Xu et al. 2004). Increased arginase activity was also observed in a mouse model of PH: in mice with monocrotaline-induced $\mathrm{PH}$, arginase activity was increased, while NOS activity and cGMP production were reduced (Sasaki et al. 2007). Of note, reduced eNOS expression and increased accumulation of endogenous NOS inhibitors, such as monomethylarginine and asymmetric dimethylarginine, also contributed to reduced NO production in this model (Sasaki et al. 2007).

Decreased plasma levels of L-arginine and NO metabolites have also been observed in infants with persistent $\mathrm{PH}$ (Pearson et al. 2001); however, whether this is caused by increased arginase activity is presently unknown. Interestingly, a recent study indicated that arginase II expression in pulmonary arteries is regulated developmentally, with maximal expression and activity during fetal life (Belik et al. 2008). It is therefore tempting to speculate that developmentally high levels of arginase activity may be involved in the pathogenesis of PPH of the newborn. 
Reduced plasma L-arginine levels and increased serum and plasma arginase activity have also been observed in patients with sickle cell anemia and associated secondary PH (Morris et al. 2003, 2005). Oral treatment with L-arginine was found to increase the plasma levels of both L-arginine and L-ornithine and to reduce pulmonary artery systolic pressure (Morris et al. 2003). The primary cause of the increased plasma arginase activity in patients with sickle cell anemia and PH may be the release of the enzyme from erythrocytes during intravascular haemolysis. Haemolysis may also contribute to reduced NO bioavailability and endothelial dysfunction via the release of erythrocyte haemoglobulin, which scavenges NO (Morris et al. 2005). Increased arginase activity in the lung and in plasma and reduced eNOS activity in the lung were observed in a mouse model of sickle cell disease and PH (Hsu et al. 2007). Similar pathobiology was observed in a nonsickle mouse model of acute alloimmune haemolysis, indicating that haemolysis is sufficient to cause these changes (Hsu et al. 2007).

In conclusion, increased arginase activity appears to be a major factor in the pathophysiology of both primary and secondary PH through its action of limiting the bioavailability of L-arginine to eNOS in the pulmonary vasculature.

\section{Conclusions}

It is a well-established fact that changes in L-arginine metabolism mediated by NO synthases are involved in a variety of diseases, including diseases of the respiratory system. During the last few years, the potential role of arginases in these diseases as key regulators of the synthesis of $\mathrm{NO}$ and of polyamines and L-proline has been attracting increasing interest. Results from animal model studies have indicated that arginase is a key factor in the regulation of airway responsiveness, and pharmacological studies using specific arginase inhibitors have revealed that this enzyme has a pathophysiological role in the pathogenesis of allergic asthma. Moreover, remarkable increases in pulmonary arginase activity and/or expression associated with altered NO and L-arginine homeostasis have been observed in animal models and human pathology of asthma, COPD, cystic fibrosis, idiopathic pulmonary fibrosis and pulmonary hypertension. Although the functional role of arginase overexpression in most of these diseases has not yet fully been established, there is accumulating evidence that arginase may be an important novel target for drug therapy of these diseases.

Acknowledgements The authors wish to thank the Netherlands Asthma Foundation (grant 00.24), the Ubbo Emmius Foundation and N.V. Organon, a part of Schering Plough corporation, Oss, the Netherlands, for financial support.
Open Access This article is distributed under the terms of the Creative Commons Attribution Noncommercial License which permits any noncommercial use, distribution, and reproduction in any medium, provided the original author(s) and source are credited.

\section{References}

Abe M, Hayashi Y, Murai A, Shibata K, Sakata N, Igarashi R, Katsuragi T, Tanaka K (2006) Effects of inducible nitric oxide synthase inhibitors on asthma depending on administration schedule. Free Radic Biol Med 40:1083-1095

Agusti AG, Villaverde JM, Togores B, Bosch M (1999) Serial measurements of exhaled nitric oxide during exacerbations of chronic obstructive pulmonary disease. Eur Respir J 14:523-528

Asano K, Chee CB, Gaston B, Lilly CM, Gerard C, Drazen JM, Stamler JS (1994) Constitutive and inducible nitric oxide synthase gene expression, regulation, and activity in human lung epithelial cells. Proc Natl Acad Sci USA 91:10089-10093

Atz AM, Wessel DL (1997) Inhaled nitric oxide in the neonate with cardiac disease. Semin Perinatol 21:441-455

Barnes PJ (1998) Nitric oxide. In: Barnes PJ, Rodger IW, Thompson NC (eds) Asthma: basic mechanism and clinical management. 3rd edn. Academic Press, London, pp 369-388

Barnes PJ, Shapiro SD, Pauwels RA (2003) Chronic obstructive pulmonary disease: molecular and cellular mechanisms. Eur Respir J 22:672-688

Belik J, Shehnaz D, Pan J, Grasemann H (2008) Developmental changes in arginase expression and activity in the lung. Am J Physiol Lung Cell Mol Physiol

Bergeron C, Boulet LP, Page N, Laviolette M, Zimmermann N, Rothenberg ME, Hamid Q (2007) Influence of cigarette smoke on the arginine pathway in asthmatic airways: increased expression of arginase I. J Allergy Clin Immunol 119:391-397

Bhowmik A, Seemungal TA, Donaldson GC, Wedzicha JA (2005) Effects of exacerbations and seasonality on exhaled nitric oxide in COPD. Eur Respir J 26:1009-1015

Boucher JL, Custot J, Vadon S, Delaforge M, Lepoivre M, Tenu JP, Yapo A, Mansuy D (1994) N-Omega-Hydroxy-L-Arginine, an intermediate in the L-Arginine to Nitric-Oxide pathway, is a strong inhibitor of liver and macrophage arginase. Biochem Biophys Res Commun 203:1614-1621

Bousquet J, Jeffery PK, Busse WW, Johnson M, Vignola AM (2000) Asthma. From bronchoconstriction to airways inflammation and remodeling. Am J Respir Crit Care Med 161:1720-1745

Brindicci C, Ito K, Resta O, Pride NB, Barnes PJ, Kharitonov SA (2005) Exhaled nitric oxide from lung periphery is increased in COPD. Eur Respir J 26:52-59

Chachaj W, Gladysz A, Puchala-Liebhart E, Wrzyszcz, Ostrowska E (1978) Carbamoyl ornithine transferase, arginase and cobaltactivated acylase in patients during asthma attacks or patients with respiratory failure. Pol Tyg Lek 33:85-88

Cirino G, Fiorucci S, Sessa WC (2003) Endothelial nitric oxide synthase: the Cinderella of inflammation? Trends Pharmacol Sci 24:91-95

Ckless K, Van der Vliet A, Janssen-Heininger Y (2007) Oxidativenitrosative stress and post-translational protein modifications: implications to lung structure-function relations. Arginase modulates NF-kappaB activity via a nitric oxide-dependent mechanism. Am J Respir Cell Mol Biol 36:645-653

Cook S, Vollenweider P, Menard B, Egli M, Nicod P, Scherrer U (2003) Increased eNO and pulmonary iNOS expression in eNOS null mice. Eur Respir J 21:770-773

Corraliza IM, Soler G, Eichmann K, Modolell M (1995) Arginase induction by suppressors of nitric oxide synthesis (IL-4, IL-10 
and PGE2) in murine bone-marrow-derived macrophages. Biochem Biophys Res Commun 206:667-673

Daghigh F, Fukuto JM, Ash DE (1994) Inhibition of rat liver arginase by an intermediate in NO biosynthesis, NG-hydroxy-L-arginine: implications for the regulation of nitric oxide biosynthesis by arginase. Biochem Biophys Res Commun 202:174-180

De Boer J, Meurs H, Coers W, Koopal M, Bottone AE, Visser AC, Timens W, Zaagsma J (1996) Deficiency of nitric oxide in allergen-induced airway hyperreactivity to contractile agonists after the early asthmatic reaction: an ex vivo study. Br J Pharmacol 119:1109-1116

De Boer J, Duyvendak M, Schuurman FE, Pouw FM, Zaagsma J, Meurs H (1999) Role of L-arginine in the deficiency of nitric oxide and airway hyperreactivity after the allergen-induced early asthmatic reaction in guinea-pigs. Br $\mathrm{J}$ Pharmacol 128:1114 1120

De Boer J, Meurs H, Flendrig L, Koopal M, Zaagsma J (2001) Role of nitric oxide and superoxide in allergen-induced airway hyperreactivity after the late asthmatic reaction in guinea-pigs. $\mathrm{Br} \mathrm{J}$ Pharmacol 133:1235-1242

De Gouw HW, Grunberg K, Schot R, Kroes AC, Dick EC, Sterk PJ (1998) Relationship between exhaled nitric oxide and airway hyperresponsiveness following experimental rhinovirus infection in asthmatic subjects. Eur Respir J 11:126-132

Downey D, Elborn JS (2000) Nitric oxide, iNOS, and inflammation in cystic fibrosis. J Pathol 190:115-116

Elphick HE, Demoncheaux EA, Ritson S, Higenbottam TW, Everard ML (2001) Exhaled nitric oxide is reduced in infants with cystic fibrosis. Thorax 56:151-152

Endo M, Oyadomari S, Terasaki Y, Takeya M, Suga M, Mori M, Gotoh T (2003) Induction of arginase I and II in bleomycininduced fibrosis of mouse lung. Am J Physiol Lung Cell Mol Physiol 285:L313-L321

Erdely A, Kepka-Lenhart D, Clark M, Zeidler-Erdely P, Poljakovic M, Calhoun WJ, Morris Jr SM (2006) Inhibition of phosphodiesterase 4 amplifies cytokine-dependent induction of arginase in macrophages. Am J Physiol Lung Cell Mol Physiol 290:L534 L539

Fajardo I, Svensson L, Bucht A, Pejler G (2004) Increased levels of hypoxia-sensitive proteins in allergic airway inflammation. Am J Respir Crit Care Med 170:477-484

Flak TA, Goldman WE (1996) Autotoxicity of nitric oxide in airway disease. Am J Respir Crit Care Med 154:S202-S206

Gaston B, Ratjen F, Vaughan JW, Malhotra NR, Canady RG, Snyder AH, Hunt JF, Gaertig S, Goldberg JB (2002) Nitrogen redox balance in the cystic fibrosis airway: effects of antipseudomonal therapy. Am J Respir Crit Care Med 165:387-390

Gebel S, Gerstmayer B, Kuhl P, Borlak J, Meurrens K, Muller T (2006) The kinetics of transcriptomic changes induced by cigarette smoke in rat lungs reveals a specific program of defense, inflammation, and circadian clock gene expression. Toxicol Sci 93:422-431

Grasemann H, Michler E, Wallot M, Ratjen F (1997) Decreased concentration of exhaled nitric oxide (NO) in patients with cystic fibrosis. Pediatr Pulmonol 24:173-177

Grasemann H, Ioannidis I, Tomkiewicz RP, de GH, Rubin BK, Ratjen F (1998) Nitric oxide metabolites in cystic fibrosis lung disease. Arch Dis Child 78:49-53

Grasemann H, Knauer N, Buscher R, Hubner K, Drazen JM, Ratjen F (2000) Airway nitric oxide levels in cystic fibrosis patients are related to a polymorphism in the neuronal nitric oxide synthase gene. Am J Respir Crit Care Med 162:2172-2176

Grasemann H, Storm van's Gravesande K, Gartig S, Kirsch M, Buscher R, Drazen JM, Ratjen F (2002) Nasal nitric oxide levels in cystic fibrosis patients are associated with a neuronal NO synthase (NOS1) gene polymorphism. Nitric Oxide 6:236-241
Grasemann H, Storm van's Gravesande K, Buscher R, Knauer N, Silverman ES, Palmer LJ, Drazen JM, Ratjen F (2003) Endothelial nitric oxide synthase variants in cystic fibrosis lung disease. Am J Respir Crit Care Med 167:390-394

Grasemann H, Grasemann C, Kurtz F, Tietze-Schillings G, Vester U, Ratjen F (2005a) Oral L-arginine supplementation in cystic fibrosis patients: a placebo-controlled study. Eur Respir J $25: 62-68$

Grasemann H, Schwiertz R, Matthiesen S, Racke K, Ratjen F (2005b) Increased Arginase Activity in Cystic Fibrosis Airways. Am J Respir Crit Care Med 1523-1528

Grasemann H, Kurtz F, Ratjen F (2006a) Inhaled L-arginine Improves Exhaled Nitric Oxide and Pulmonary Function in Cystic Fibrosis Patients. Am J Respir Crit Care Med 174:208-212

Grasemann H, Schwiertz R, Grasemann C, Vester U, Racke K, Ratjen F (2006b) Decreased systemic bioavailability of Larginine in patients with cystic fibrosis. Respir Res 7:87

Gray MJ, Poljakovic M, Kepka-Lenhart D, Morris SM Jr. (2005) Induction of arginase I transcription by IL-4 requires a composite DNA response element for STAT6 and C/EBPbeta. Gene 353:98-106

Greene AL, Rutherford MS, Regal RR, Flickinger GH, Hendrickson JA, Giulivi C, Mohrman ME, Fraser DG, Regal JF (2005) Arginase activity differs with allergen in the effector phase of ovalbuminversus trimellitic anhydride-induced asthma. Toxicol Sci 88: $420-433$

Gross TJ, Hunninghake GW (2001) Idiopathic pulmonary fibrosis. N Engl J Med 345:517-525

Hamid Q, Springall DR, Riveros-Moreno V, Chanez P, Howarth P, Redington A, Bousquet J, Godard P, Holgate S, Polak JM (1993) Induction of nitric oxide synthase in asthma. Lancet 342:1510-1513

Hays SR, Ferrando RE, Carter R, Wong HH, Woodruff PG (2005) Structural changes to airway smooth muscle in cystic fibrosis. Thorax 60:226-228

Hey C, Boucher JL, Vadon-Le Goff S, Ketterer G, Wessler I, Racké K (1997) Inhibition of arginase in rat and rabbit alveolar macrophages by $\mathrm{N}$ omega-hydroxy-D,L-indospicine, effects on Larginine utilization by nitric oxide synthase. Br J Pharmacol 121:395-400

Hilliard TN, Regamey N, Shute JK, Nicholson AG, Alton EW, Bush A, Davies JC (2007) Airway remodelling in children with cystic fibrosis. Thorax 62:1074-1080

Hobbs CA, Gilmour SK (2000) High levels of intracellular polyamines promote histone acetyltransferase activity resulting in chromatin hyperacetylation. J Cell Biochem 77:345-360

Hoet PH, Nemery B (2000) Polyamines in the lung: polyamine uptake and polyamine-linked pathological or toxicological conditions. Am J Physiol Lung Cell Mol Physiol 278:L417-L433

Hogg JC (2004) Pathophysiology of airflow limitation in chronic obstructive pulmonary disease. Lancet 364:709-721

Hoyt JC, Robbins RA, Habib M, Springall DR, Buttery LD, Polak JM, Barnes PJ (2003) Cigarette smoke decreases inducible nitric oxide synthase in lung epithelial cells. Exp Lung Res 29:17-28

Hsu LL, Champion HC, Campbell-Lee SA, Bivalacqua TJ, Manci EA, Diwan BA, Schimel DM, Cochard AE, Wang X, Schechter AN, Noguchi CT, Gladwin MT (2007) Hemolysis in sickle cell mice causes pulmonary hypertension due to global impairment in nitric oxide bioavailability. Blood 109:3088-3098

Hutchison SJ, Sievers RE, Zhu BQ, Sun YP, Stewart DJ, Parmley WW, Chatterjee K (2001) Secondhand tobacco smoke impairs rabbit pulmonary artery endothelium-dependent relaxation. Chest 120:2004-2012

Ichinose M, Sugiura H, Yamagata S, Koarai A, Shirato K (2000) Increase in reactive nitrogen species production in chronic obstructive pulmonary disease airways. Am J Respir Crit Care Med 162:701-706 
Imamura M, Waseda Y, Marinova GV, Ishibashi T, Obayashi S, Sasaki A, Nagai A, Azuma H (2007) Alterations of NOS, arginase, and DDAH protein expression in rabbit cavernous tissue after administration of cigarette smoke extract. Am J Physiol Regul Integr Comp Physiol 293:R2081-R2089

Ito K, Caramori G, Lim S, Oates T, Chung KF, Barnes PJ, Adcock IM (2002) Expression and activity of histone deacetylases in human asthmatic airways. Am J Respir Crit Care Med 166:392-396

Jeffery PK (2000) Comparison of the structural and inflammatory features of COPD and asthma. Giles F. Filley Lecture. Chest 117:251S-260S

Jenkinson CP, Grody WW, Cederbaum SD (1996) Comparative properties of arginases. Comp Biochem Physiol B Biochem Mol Biol 114:107-132

Kaneko FT, Arroliga AC, Dweik RA, Comhair SA, Laskowski D, Oppedisano R, Thomassen MJ, Erzurum SC (1998) Biochemical reaction products of nitric oxide as quantitative markers of primary pulmonary hypertension. Am J Respir Crit Care Med 158:917-923

Kharitonov SA, Barnes PJ (2001) Exhaled markers of pulmonary disease. Am J Respir Crit Care Med 163:1693-1722

Kharitonov SA, Yates D, Robbins RA, Logan-Sinclair R, Shinebourne EA, Barnes PJ (1994) Increased nitric oxide in exhaled air of asthmatic patients. Lancet 343:133-135

Kharitonov S, O'connor BJ, Evans DJ, Barnes PJ (1995a) Allergeninduced late asthmatic reactions are associated with elevation of exhaled nitric oxide. Am J Respir Crit Care Med 151:1894-1897

Kharitonov SA, Robbins RA, Yates D, Keatings V, Barnes PJ (1995b) Acute and chronic effects of cigarette smoking on exhaled nitric oxide. Am J Respir Crit Care Med 152:609-612

Kitowska K, Zakrzewicz D, Konigshoff M, Chrobak I, Grimminger F, Seeger W, Bulau P, Eickelberg O (2008) Functional Role and Species-specific Contribution of Arginases in Pulmonary Fibrosis. Am J Physiol Lung Cell Mol Physiol 294:L34-L45

Klasen S, Hammermann R, Fuhrmann M, Lindemann D, Beck KF, Pfeilschifter J, Racke K (2001) Glucocorticoids inhibit lipopolysaccharide-induced up-regulation of arginase in rat alveolar macrophages. Br J Pharmacol 132:1349-1357

Kochanski L, Kossmann S, Rogala E, Dwornicki J (1980) Sputum arginase activity in bronchial asthma. Pneumonol Pol 48:329332

Kuo HP, Liu S, Barnes PJ (1992) The effect of endogenous nitric oxide on neurogenic plasma exudation in guinea-pig airways. Eur J Pharmacol 221:385-388

Kurosawa M, Shimizu Y, Tsukagoshi H, Ueki M (1992) Elevated levels of peripheral-blood, naturally occurring aliphatic polyamines in bronchial asthmatic patients with active symptoms. Allergy 47:638-643

Lewis CC, Yang JY, Huang X, Banerjee SK, Blackburn MR, Baluk P, McDonald DM, Blackwell TS, Nagabhushanam V, Peters W, Voehringer D, Erle DJ (2007) Disease-specific gene expression profiling in multiple models of lung disease. Am J Respir Crit Care Med 177:376-387

Li H, Romieu I, Sienra-Monge JJ, Ramirez-Aguilar M, Estela DR-N, Kistner EO, Gjessing HK, Lara-Sanchez IC, Chiu GY, London SJ (2006) Genetic polymorphisms in arginase I and II and childhood asthma and atopy. J Allergy Clin Immunol 117:119-126

Lindemann D, Racke K (2003) Glucocorticoid inhibition of interleukin-4 (IL-4) and interleukin-13 (IL-13) induced upregulation of arginase in rat airway fibroblasts. Naunyn Schmiedebergs Arch Pharmacol 368:546-550

Maarsingh H, Bossenga BB, Bos IST, Zaagsma J, Meurs H (2004) Arginase-and polycation-induced L-arginine limitation causes deficiency of bronchodilating NO and airway hyperreactivity after the late asthmatic reaction. Eur Respir J 24[Suppl 48]:681s

Maarsingh H, Tio MA, Zaagsma J, Meurs H (2005) Arginase attenuates inhibitory nonadrenergic noncholinergic nerve-induced nitric oxide generation and airway smooth muscle relaxation. Respir Res 6:23

Maarsingh H, Leusink J, Bos IST, Zaagsma J, Meurs H (2006) Arginase strongly impairs neuronal nitric oxide-mediated airway smooth muscle relaxation in allergic asthma. Respir Res 7:6

Marshall HE, Stamler JS (2001) Inhibition of NF-kappa B by Snitrosylation. Biochemistry 40:1688-1693

Maziak W, Loukides S, Culpitt S, Sullivan P, Kharitonov SA, Barnes PJ (1998) Exhaled nitric oxide in chronic obstructive pulmonary disease. Am J Respir Crit Care Med 157:998-1002

Mehta S, Drazen JM, Lilly CM (1997) Endogenous nitric oxide and allergic bronchial hyperresponsiveness in guinea pigs. Am J Physiol 273:L656-L662

Meurs H, Hamer MA, Pethe S, Vadon-Le Goff S, Boucher JL, Zaagsma J (2000) Modulation of cholinergic airway reactivity and nitric oxide production by endogenous arginase activity. Br J Pharmacol 130:1793-1798

Meurs H, McKay S, Maarsingh H, Hamer MA, Macic L, Molendijk N, Zaagsma J (2002) Increased arginase activity underlies allergeninduced deficiency of cNOS-derived nitric oxide and airway hyperresponsiveness. Br J Pharmacol 136:391-398

Meurs H, Maarsingh H, Zaagsma J (2003) Arginase and asthma: novel insights into nitric oxide homeostasis and airway hyperresponsiveness. Trends Pharmacol Sci 24:450-455

Mhanna MJ, Ferkol T, Martin RJ, Dreshaj IA, Van Heeckeren AM, Kelley TJ, Haxhiu MA (2001) Nitric oxide deficiency contributes to impairment of airway relaxation in cystic fibrosis mice. Am J Respir Cell Mol Biol 24:621-626

Misson P, Van den Brûle S, Barbarin V, Lison D, Huaux F (2004) Markers of macrophage differentiation in experimental silicosis. J Leukoc Biol 76:926-932

Modolell M, Corraliza IM, Link F, Soler G, Eichmann K (1995) Reciprocal regulation of the nitric oxide synthase/arginase balance in mouse bone marrow-derived macrophages by TH1 and TH2 cytokines. Eur J Immunol 25:1101-1104

Moncada S, Palmer RM, Higgs EA (1989) Biosynthesis of nitric oxide from L-arginine. A pathway for the regulation of cell function and communication. Biochem Pharmacol 38:17091715

Mora AL, Torres-Gonzalez E, Rojas M, Corredor C, Ritzenthaler J, Xu J, Roman J, Brigham K, Stecenko A (2006) Activation of alveolar macrophages via the alternative pathway in herpes virusinduced lung fibrosis. Am J Respir Cell Mol Biol 35:466-473

Morris CR, Morris SM, Hagar W, Van Warmerdam J, Claster S, Kepka-Lenhart D, Machado L, Kuypers FA, Vichinsky EP (2003) Arginine therapy- A new treatment for pulmonary hypertension in sickle cell disease? Am J Respir Crit Care Med 168:63-69

Morris CR, Poljakovic M, Lavrisha L, Machado L, Kuypers FA, Morris SM Jr (2004) Decreased arginine bioavailability and increased serum arginase activity in asthma. Am J Respir Crit Care Med 170:148-153

Morris CR, Kato GJ, Poljakovic M, Wang X, Blackwelder WC, Sachdev V, Hazen SL, Vichinsky EP, Morris SM Jr, Gladwin MT (2005) Dysregulated arginine metabolism, hemolysis-associated pulmonary hypertension, and mortality in sickle cell disease. JAMA 294:81-90

Muijsers RB, Van Ark I, Folkerts G, Koster AS, Van Oosterhout AJ, Postma DS, Nijkamp FP (2001) Apocynin and $1400 \mathrm{~W}$ prevents airway hyperresponsiveness during allergic reactions in mice. $\mathrm{Br}$ J Pharmacol 134:434-440

Munder M, Mollinedo F, Calafat J, Canchado J, Gil-Lamaignere C, Fuentes JM, Luckner C, Doschko G, Soler G, Eichmann K, Muller FM, Ho AD, Goerner M, Modolell M (2005) Arginase I is constitutively expressed in human granulocytes and participates in fungicidal activity. Blood 105:2549-2556 
Nelin LD, Krenz GS, Chicoine LG, Dawson CA, Schapira RM (2002) L-Arginine uptake and metabolism following in vivo silica exposure in rat lungs. Am J Respir Cell Mol Biol 26:348-355

Nelin LD, Chicoine LG, Reber KM, English BK, Young TL, Liu Y (2005) Cytokine-induced endothelial arginase expression is dependent on epidermal growth factor receptor. Am J Respir Cell Mol Biol 33:394-401

Olson JW (1985) Chronic cigarette sidestream smoke exposure increases rat trachea ornithine decarboxylase activity. Life Sci $37: 2165-2171$

Olson JW, Crooks PA (1985) Effect of nicotine and N'-nitrosonornicotine on rat lung and trachea ornithine decarboxylase activity. Carcinogenesis 6:1517-1519

Pauwels RA, Buist AS, Calverley PM, Jenkins CR, Hurd SS (2001) Global strategy for the diagnosis, management, and prevention of chronic obstructive pulmonary disease. NHLBI/WHO Global Initiative for Chronic Obstructive Lung Disease (GOLD) Workshop summary. Am J Respir Crit Care Med 163:1256-1276

Pearson DL, Dawling S, Walsh WF, Haines JL, Christman BW, Bazyk A, Scott N, Summar ML (2001) Neonatal pulmonary hypertension-urea-cycle intermediates, nitric oxide production, and carbamoyl-phosphate synthetase function. N Engl J Med 344:1832-1838

Poljakovic M, Porter DW, Millecchia L, Kepka-Lenhart D, Beighley C, Wolfarth MG, Castranova V, Morris SM Jr (2007) Cell-and isoform-specific increases in arginase expression in acute silicainduced pulmonary inflammation. J Toxicol Environ Health A 70:118-127

Postma DS, Kerstjens HA (1998) Characteristics of airway hyperresponsiveness in asthma and chronic obstructive pulmonary disease. Am J Respir Crit Care Med 158:S187-S192

Que LG, Kantrow SP, Jenkinson CP, Piantadosi CA, Huang YC (1998) Induction of arginase isoforms in the lung during hyperoxia. Am J Physiol 275:L96-102

Renkema TE, Postma DS, Noordhoek JA, Sluiter HJ, Kauffman HF (1991) In vitro release of neutrophil elastase, myeloperoxidase and beta-glucuronidase in patients with emphysema and healthy subjects. Eur Respir J 4:1237-1244

Ricciardolo FLM (2003) Multiple roles of nitric oxide in the airways. Thorax 58:175-182

Ricciardolo FLM, DiMaria GU, Mistretta A, Sapienza MA, Geppetti P (1997) Impairment of bronchoprotection by nitric oxide in severe asthma. Lancet 350:1297-1298

Ricciardolo FL, Timmers MC, Geppetti P, Van Schadewijk A, Brahim JJ, Sont JK, De Gouw HW, Hiemstra PS, Van Krieken JH, Sterk PJ (2001) Allergen-induced impairment of bronchoprotective nitric oxide synthesis in asthma. J Allergy Clin Immunol 108:198-204

Ricciardolo FL, Sterk PJ, Gaston B, Folkerts G (2004) Nitric oxide in health and disease of the respiratory system. Physiol Rev 84:731-765

Ricciardolo FL, Zaagsma J, Meurs H (2005) The therapeutic potential of drugs targeting the arginase pathway in asthma. Expert Opin Investig Drugs 14:1221-1231

Robbins RA, Hadeli K, Nelson D, Sato E, Hoyt JC (2000) Nitric oxide, peroxynitrite, and lower respiratory tract inflammation. Immunopharmacology 48:217-221

Rutschman R, Lang R, Hesse M, Ihle JN, Wynn TA, Murray PJ (2001) Cutting edge: Stat6-dependent substrate depletion regulates nitric oxide production. J Immunol 166:2173-2177

Sadeghi-Hashjin G, Folkerts G, Henricks PAJ, Verheyen AKCP, Van der Linde HJ, Van Ark I, Coene A, Nijkamp FP (1996) Peroxynitrite induces airway hyperresponsiveness in guinea pigs in vitro and in vivo. Am J Respir Crit Care Med 153:1697-1701

Sadeghi-Hashjin G, Folkerts G, Henricks PAJ, Muijsers RBR, Nijkamp FP (1998) Peroxynitrite in airway diseases. Clin Exp Allergy 28:1464-1473
Saleh D, Ernst P, Lim S, Barnes PJ, Giaid A (1998) Increased formation of the potent oxidant peroxynitrite in the airways of asthmatic patients is associated with induction of nitric oxide synthase: effect of inhaled glucocorticoid. FASEB J 12:929-937

Samb A, Pretolani M, Dinh-Xuan AT, Ouksel H, Callebert J, Lisdero C, Aubier M, Boczkowski J (2001) Decreased pulmonary and tracheal smooth muscle expression and activity of type 1 nitric oxide synthase (nNOS) after ovalbumin immunization and multiple aerosol challenge in guinea pigs. Am J Respir Crit Care Med 164:149-154

Sandler NG, Mentink-Kane MM, Cheever AW, Wynn TA (2003) Global gene expression profiles during acute pathogen-induced pulmonary inflammation reveal divergent roles for Th1 and Th2 responses in tissue repair. J Immunol 171:3655-3667

Sasaki A, Doi S, Mizutani S, Azuma H (2007) Roles of accumulated endogenous nitric oxide synthase inhibitors, enhanced arginase activity, and attenuated nitric oxide synthase activity in endothelial cells for pulmonary hypertension in rats. Am J Physiol Lung Cell Mol Physiol 292:L1480-L1487

Satriano J (2004) Arginine pathways and the inflammatory response: interregulation of nitric oxide and polyamines: review article. Amino Acids 26:321-329

Schapira RM, Wiessner JH, Morrisey JF, Almagro UA, Nelin LD (1998) L-arginine uptake and metabolism by lung macrophages and neutrophils following intratracheal instillation of silica in vivo. Am J Respir Cell Mol Biol 19:308-315

Schuiling M, Meurs H, Zuidhof AB, Venema N, Zaagsma J (1998a) Dual action of iNOS-derived nitric oxide in allergen-induced airway hyperreactivity in conscious, unrestrained guinea pigs. Am J Respir Crit Care Med 158:1442-1449

Schuiling M, Zuidhof AB, Bonouvrie MA, Venema N, Zaagsma J, Meurs H (1998b) Role of nitric oxide in the development and partial reversal of allergen-induced airway hyperreactivity in conscious, unrestrained guinea-pigs. $\mathrm{Br} \mathrm{J}$ Pharmacol 123: $1450-1456$

Sharkhuu T, Matthaei KI, Forbes E, Mahalingam S, Hogan SP, Hansbro PM, Foster PS (2006) Mechanism of interleukin-25 (IL-17E)-induced pulmonary inflammation and airways hyperreactivity. Clin Exp Allergy 36:1575-1583

Shearer JD, Richards JR, Mills CD, Caldwell MD (1997) Differential regulation of macrophage arginine metabolism: a proposed role in wound healing. Am J Physiol 272:E181-E190

Sutherland ER, Martin RJ (2003) Airway inflammation in chronic obstructive pulmonary disease: comparisons with asthma. J Allergy Clin Immunol 112:819-827

Tadie JM, Henno P, Leroy I, Danel C, Naline E, Faisy C, Riquet M, Levy M, Israel-Biet D, Delclaux C (2008) Role of the nitric oxide synthase/arginase balance on bronchial reactivity in patients with chronic obstructive pulmonary disease. Am J Physiol Lung Cell Mol Physiol 294:L489- L497

Takemoto K, Shibamori M, Hitomi Y, Takigawa T, Wang DH, Ichimura H, Fujikura Y, Ogino K (2007) Transiently, paralleled upregulation of arginase and nitric oxide synthase and the effect of both enzymes on the pathology of asthma. Am J Physiol Lung Cell Mol Physiol 293:L1419-L1426

Ten Broeke R, De CR, Van Haperen R, Verweij V, LeusinkMuis T, Van Ark I, De Clerck F, Nijkamp FP, Folkerts G (2006) Overexpression of endothelial nitric oxide synthase suppresses features of allergic asthma in mice. Respir Res 7:58

Thomassen MJ, Buhrow LT, Connors MJ, Kaneko FT, Erzurum SC, Kavuru MS (1997) Nitric oxide inhibits inflammatory cytokine production by human alveolar macrophages. Am J Respir Cell Mol Biol 17:279-283

Thyberg J, Fredholm BB (1987a) Induction of ornithine decarboxylase activity and putrescine synthesis in arterial smooth-muscle 
cells stimulated with platelet-derived growth-factor. Exp Cell Res 170:160-169

Thyberg J, Fredholm BB (1987b) Modulation of arterial smoothmuscle cells from contractile to synthetic phenotype requires induction of ornithine decarboxylase activity and polyamine synthesis. Exp Cell Res 170:153-159

Tiddens HA, De Jong PA (2007) Imaging and clinical trials in cystic fibrosis. Proc Am Thorac Soc 4:343-346

Wang WW, Jenkinson CP, Griscavage JM, Kern RM, Arabolos NS, Byrns RE, Cederbaum SD, Ignarro LJ (1995) Co-induction of arginase and nitric oxide synthase in murine macrophages activated by lipopolysaccharide. Biochem Biophys Res Commun 210:1009-1016

Wei LH, Jacobs AT, Morris SM Jr, Ignarro LJ (2000) IL-4 and IL-13 upregulate arginase I expression by cAMP and JAK/STAT6 pathways in vascular smooth muscle cells. Am J Physiol Cell Physiol 279:C248-C256

Wei LH, Wu G, Morris SM Jr, Ignarro LJ (2001) Elevated arginase I expression in rat aortic smooth muscle cells increases cell proliferation. Proc Natl Acad Sci USA 98:9260-9264

Wu G, Morris SM (1998) Arginine metabolism: nitric oxide and beyond. Biochem J 336:1-17

Xia Y, Zweier JL (1997) Superoxide and peroxynitrite generation from inducible nitric oxide synthase in macrophages. Proc Natl Acad Sci USA 94:6954-6958
Xia Y, Roman LJ, Masters BS, Zweier JL (1998) Inducible nitricoxide synthase generates superoxide from the reductase domain. J Biol Chem 273:22635-22639

Xu W, Kaneko FT, Zheng S, Comhair SA, Janocha AJ, Goggans T, Thunnissen FB, Farver C, Hazen SL, Jennings C, Dweik RA, Arroliga AC, Erzurum SC (2004) Increased arginase II and decreased NO synthesis in endothelial cells of patients with pulmonary arterial hypertension. FASEB J 18:1746-1748

Yan ZQ, Hanson GK, Skoogh BE, Lotvall JO (1995) Induction of nitric oxide synthase in a model of allergic occupational asthma. Allergy 50:760-764

Yang M, Rangasamy D, Matthaei KI, Frew AJ, Zimmmermann N, Mahalingam S, Webb DC, Tremethick DJ, Thompson PJ, Hogan SP, Rothenberg ME, Cowden WB, Foster PS (2006) Inhibition of arginase I activity by RNA interference attenuates IL-13-induced airways hyperresponsiveness. J Immunol 177:5595-5603

Zimmermann N, King NE, Laporte J, Yang M, Mishra A, Pope SM, Muntel EE, Witte DP, Pegg AA, Foster PS, Hamid Q, Rothenberg ME (2003) Dissection of experimental asthma with DNA microarray analysis identifies arginase in asthma pathogenesis. J Clin Invest 111:1863-1874

Zuyderduyn S, Ninabar DK, Fens N, Maarsingh H, Meurs H, Sterk PJ, Hiemstra PS, Rabe KF (2006) IL-4 enhances arginase-2 expression in human airway smooth muscle cells (HASM). Proc Am Thoracic Soc 3:A462 